\title{
Circ-DLG I promotes the proliferation of esophageal squamous cell carcinoma [Erratum]
}

Rong J, Wang Q, Zhang Y, et al. Onco Targets Ther. 2018;11: 6723-6730.

On page 6723, Xiu-feng Cao correspondence details were incorrectly listed as Correspondence: Xiu-feng Cao Department of Oncology Surgery, Nanjing First Hospital, 68 Changle Road, Nanjing 210006, China

Email cxf551101@sina.com

The correct details are Correspondence: Xiu-feng Cao Department of Thoracic Surgery, Taikang Xianlin Drum Tower Hospital, School of Medicine, Nanjing University, Nanjing 210023, China

Email cxf551101@sina.com

\section{Publish your work in this journal}

OncoTargets and Therapy is an international, peer-reviewed, open access journal focusing on the pathological basis of all cancers, potential targets for therapy and treatment protocols employed to improve the management of cancer patients. The journal also focuses on the impact of management programs and new therapeutic agents and protocols on

ERRATUM

Submit your manuscript here: http://www.dovepress.com/oncotargets-and-therapy-journal

patient perspectives such as quality of life, adherence and satisfaction. The manuscript management system is completely online and includes a very quick and fair peer-review system, which is all easy to use. Visit http://www.dovepress.com/testimonials.php to read real quotes from published authors. 